Medial ve Lateral Menisküslerin Radyal Yırtıklarında MRG ve Eşlik Eden Diz Eklemi Patolojileri

\title{
Mrı and Accompanying Knee Pathologies in the Radial Tears of Medial and Lateral Menisci
}

\section{Yüksel Işık}

Beykoz Devlet Hastanesi, Radyoloji Bölümü, İstanbul, Türkiye

\section{$\ddot{O} Z$}

GíRiŞ ve AMAÇ: Bu çalışmanın amact, medial ve lateral menisküslerde izlenen radyal yırtıkların manyetik rezonans görüntüleme (MRG) bulgularını ve bu yırtık tipinin, eşlik eden diz patolojileri ile ilişkisini ortaya koymaktır.

YÖNTEM ve GEREÇLER: Bu çalışmada retrospektif olarak 30 hastanın MRG incelemesi PACS üzerinde değerlendirildi. $M R G$ bulguları retrospektif olarak kas iskelet tercübesi olan 2 radyolog tarafindan yorumlandı. Çalı̧̧maya, pür radyal yırtığ olan hastalar dahil edildi. Diz MRG incelemeleri yapılmış ve radyal yırtık tespit edilen 30 olgu belirlenerek verileri kaydedildi. 30 hastadan 22'si merkezimizde atroskopik operasyon geçirmiş olup, 22'sinde de MRG bulguları ile uyumlu şekilde radyal yırtık olduğu konfirme edildi.

BULGULAR: 30 olgunun 17'sinde medial menisküste $(\% 56,7)$, 13'ünde lateral menisküste $(\% \% 43,3)$ radyal ylrtık saptadı. Medial menisküste $11(\% 36,7)$ olguda ekstrüzyon $(\geq 3 \mathrm{~mm})$, lateral menisküste $7(\% 23,3)$ olguda ekstrüzyon görülmektedir Bu çalışmada, radyal yırtığa en sık eşlik eden ligaman patolojisi ön çapraz bă̆ (ÖÇB) (17 olgu \%56,9) olarak saptanmıştır. Radyal yırtık ile kıkırdak patolojileri arasındaki ilişki değerlendirildiğinde; En sık medial patellar fasette (MPF) $26(\% 86,6)$ kondromalazi saptand.

TARTISSMA ve SONUÇ: Radyal yırtıklar sıklikla medial menisküste meydana gelirler. Medial meniskal radyal yırtıklarda mediale ekstrüzyon ( $\geq 3 \mathrm{~mm}$ ) sik eşlik ederken, lateral meniskal radyal yırtıklarda laterale ekstrüzyon daha az rastalanilır. Radyal meniskal yırtıklarda en sik ligaman patolojisi, arka çapraz bağda görülür. Radyal yırtık ile dejeneratif kıkırdak hastalı̆̆ ilişkisinde, en sık MPF kıkırdağının etkilendiği izlenmektedir. Medial menisküs ekstrüzyonu ile kıkırdak dejenerasyonu arasında belirgin iliski mevcut iken, lateral menisküs ekstrüzyonu ile kıkırdak dejenerasyonu arasında belirgin ilişki korele edilemedi.

Anahtar Kelimeler: Radyal yırtık, menisküs, ligament, kıkırdak dejenerasyonu

\begin{abstract}
INTRODUCTION: The aim of this study is to demonstrate magnetic resonance imaging (MRI) findings of radial tears that are seen in the medial and lateral menisci and the relationship between this tear type and other accompanying knee pathologies
\end{abstract}

METHODS: In this study, the MRI examinations of 30 patients were evaluated on PACS retrospectively. The MRI findings were interpreted by two different radiologists who were experienced in musculoskeletal radiology. Only the patients who revealed radial tears on MRI were included in the study. Out of 30 patients, 22 underwent arthroscopic operation in our center and all of them were confirmed to have radial tears in accordance with the MRI findings.

RESULTS: Extrusion ( $\geq 3 \mathrm{~mm}$ ) was observed in the medial meniscus of 11 cases (36.7\%) and in the lateral meniscus of seven cases $(23.3 \%)$. In this study, the most common accompanying ligament pathology was in the anterior cruciate ligament (ACL) (17 cases, 56.9\%). When the relationship between radial tear and cartilage pathologies was evaluated; cartilage degeneration frequently was found in the medial patellar facet (MPF) of 26 cases $(86.6 \%)$ patients.

DISCUSSION AND CONCLUSION: Medial meniscal radial tears are frequently accompanied with extrusion to medial $(\geq 3$ $\mathrm{mm}$ ). ACL pathology is the most common ligament pathology in radial meniscal tears. It is observed that MPF cartilage are frequently affected in relation to radial tear and degenerative cartilage disease. There is a significant relationship between medial meniscal extrusion and cartilage degeneration.

Keywords: Radial tear, menisci, ligament, cartilage degeneration

Iletişim / Correspondence:

Yüksel Işı k

Beykoz Devlet Hastanesi, Radyoloji Bölümü, İstanbul, Türkiye

E-mail: yukselisikk@hotmail.com

Başvuru Tarihi: 23.04.2018

Kabul Tarihi: 26.10.2018 


\section{INTRODUCTION}

Meniscal tears are commonly observed orthopedic pathologies and magnetic resonance imaging (MRI) has high accuracy in detecting meniscal tears. Meniscal tears appear in several different configurations and they have different clinical effects. Preoperative characterization of meniscal tears is effective on operation planning and prognosis. Therefore, attention should be paid while defining meniscal tear on MR images (1-5).

Radial tears are the tears which are perpendicularly oriented to the long circumferential axis of meniscus. They may extend from the apex to the periphery of meniscus and may be fullthickness or partial thickness.If it extends from the inner part of meniscus to a certain part, it is called incomplete radial tear. It may frequently be associated with other complex tears $(1,6,7)$. The detection of radial tears on MR images can sometimes be quite difficult (6).

Radial tears may occur secondary to trauma or degenerative changes and they may appear in both menisci at any localization $(1,2)$. In case of radial tears, loss of meniscal integrity destroys the ability of meniscus to dissipate "hoop stress" and may impair the function of meniscus and may cause degenerative changes and abrasion in the affected joint $(1,2,8)$. They are usually treated with debridement. They are rarely repaired and the radiologic detection of radial tears alerts the clinician in terms of being more cautious in preoperative planning $(2,4)$.

The aim of this study is to correlate the MRI findings of radial meniscal tears and the pathologies of radial meniscal tears with other anatomic structures of knee.

\section{MATERIALS AND METHODS}

Three thousand one hundred twenty-three patients who had knee MRI between the dates of October 2013 and February 2017 and 3782 knee MRI examinations of these patients were evaluated retrospectively on PACS. Only the patients who revealed radial tears on MRI were included in the study. The patients who had previous knee surgery history, complex meniscal tears, and inflammatory knee pathology were not included in the study. 30 patients who had knee MRI examinations and who were detected to have radial tears radiologically were determined and their data were recorded. Out of 30 patients, 22 underwent arthroscopic operation in our center and all of them were confirmed to have radial tears in accordance with the MRI findings.
The examinations were performed using 3 Tesla MRI (Ingenia, Philips,TheNetherlands) and 16-channel SENSE knee coil in our hospital. The patient to be visualized in the MRI device was firstly placed in supine position within the MRI device in a way that their feet would come out first. The knee was placed close to the anatomical position in the coil so that it would be in slight flexion and minimal external rotation.

Routinely, sagittal and axial fat-suppressed PD, coronal fat-suppressed T2, coronal PD and 3D VISTA sequences were obtained from the knee MRI of patient. The scan duration was 25 minutes in total for routine sequences. The sequence parameters that were examined in the study were given in Table 1.

\begin{tabular}{|c|c|c|c|c|c|}
\hline Parameters & $\begin{array}{l}\text { T2 Spair } \\
\text { Coronal }\end{array}$ & $\begin{array}{l}\text { Pd } \\
\text { Sagittal }\end{array}$ & $\begin{array}{l}\text { Pd } \\
\text { Spair } \\
\text { Axıal }\end{array}$ & $\begin{array}{l}\text { Pd } \\
\text { Spair } \\
\text { Coronal }\end{array}$ & 3d Pd Vista \\
\hline $\begin{array}{l}\text { Slice } \\
\text { thickness } \\
(\mathbf{m m})\end{array}$ & 3.5 & 3 & 3 & 2.5 & 0.8 \\
\hline Slices & 25 & 28 & 32 & 35 & 35 \\
\hline $\begin{array}{l}\text { FOV (AP) } \\
(\mathbf{c m})\end{array}$ & 15 & 15 & 14 & 12 & 16 \\
\hline $\begin{array}{l}\text { Data } \\
\text { matrix }\end{array}$ & $308 \times 214$ & $524 \times 864$ & $300 \times 356$ & $480 \times 292$ & $251 \times 512$ \\
\hline $\begin{array}{l}\text { TR } \\
(\mathbf{m s}) / \mathrm{TE} \\
(\mathrm{ms})\end{array}$ & $3700 / 62$ & $3982 / 30$ & $5602 / 30$ & $3218 / 30$ & $1300 / 28$ \\
\hline $\begin{array}{l}\text { Voxel size } \\
(\mathbf{m m})\end{array}$ & $0.5 \times 0.7 \times 3.5$ & $0.4 \times 0.3$ & $0.4 \times 0.3$ & $0.2 \times 0.3$ & $0.5 \times 0.5 \times 0.5$ \\
\hline $\begin{array}{l}\text { Scan } \\
\text { duration } \\
\text { (minutes) }\end{array}$ & $3: 42$ & $3: 27$ & $2: 16$ & $3: 32$ & $5: 22$ \\
\hline
\end{tabular}

The MRI images were evaluated retrospectively by two radiologists who did not see the reports before the operation, who had musculoskeletal radiology experience for 15 years and 6 years and who worked in different centers. Thirty patients on whom they reached a common consensus regarding radial tears were included in the study.

The radial tear diagnosis was made in the presence of truncation sign, cleft sign and ghostly meniscus sign. The truncation sign was defined as blunting of normal triangular meniscal contour on sagittal and coronal images. The cleft sign was defined as linear-vertical high signal extending along the meniscus on coronal or sagittal MRI images. The ghostly meniscus sign was assessed as complete absence of meniscus on MRI images that pass from the level of full-thickness radial tears (2).

Medial meniscal extrusion is defined as significant medial displacement of medial meniscus with respect to the central margin of medial tibial plateau. Pathologic medial meniscal extrusion was defined as a distance that is $\geq 3 \mathrm{~mm}$ (9). Lateral meniscal extrusion was diagnosed when the longest 
distance from the peripheral margin of meniscal body to the peripheral margin of tibial articular cartilage was greater than $1 \mathrm{~mm}$ on any of the middle three coronal sections obtained through the meniscal body (10).

The grading of cartilage pathology was performed via MRI images according to the Outerbridge classification (11). Cartilage degeneration grades according to the Outerbridge classification were as following: normal: intact cartilage; mild injury: chondral softening or swelling; moderate injury: superficial ulceration, fibrillation, fissure formation which involve less than $50 \%$ of the articular surface; advanced injury: deep ulcerations, fibrillation, fissure which involve more than $50 \%$ of the articular surface or chondral flap where the subchondral bone is not affected; full-thickness chondral injury is defined as fullthickness chondral abrasion along with subchondral bone.

The grading of ligament injuries was carried out as described in the literature. Accordingly, mild injury of crucial ligaments was defined as intraligamentary focally increased signal; partial tear was defined as intraligamentary diffusely increased signal, or partial discontinuity of fibers; complete tear was defined as complete discontinuity of ligament (12). Grade 1 (mild injury) in collateral ligaments was described as edema in the soft tissue planes around collateral ligaments; Grade 2 (severe injury or partial tear) was described as high signal or partial absence of the collateral ligament itself in addition to grade 1 pathology; Grade 3 (complete tear) was described as discontinuity of collateral ligaments (13).

There is no conflict of interest statement. We didn't use of laboratory animals.

This report is an IRB approved study. We have obtained informed constent form from the patient.

\section{RESULTS}

Of 30 cases who were evaluated in this study, 19 were male $(63.33 \%)$ and 11 were female $(36.7 \%)$. The youngest patient was 21 years old while the oldest patient was 75 years old. The mean age of the cases was 54.5 years. In 30 cases, a radial tear was detected in the medial meniscus $(56.7 \%)$ of 17 case and in the lateral meniscus $(43.3 \%)$ of 13 cases. Of the radial tears that were observed in the medial meniscus, eight $(26.7 \%)$ were focal, nine $(30 \%)$ were focal while in the lateral meniscus, nine (30\%) were focal (Fig. 1A-B) and four (13.3\%) were complete.
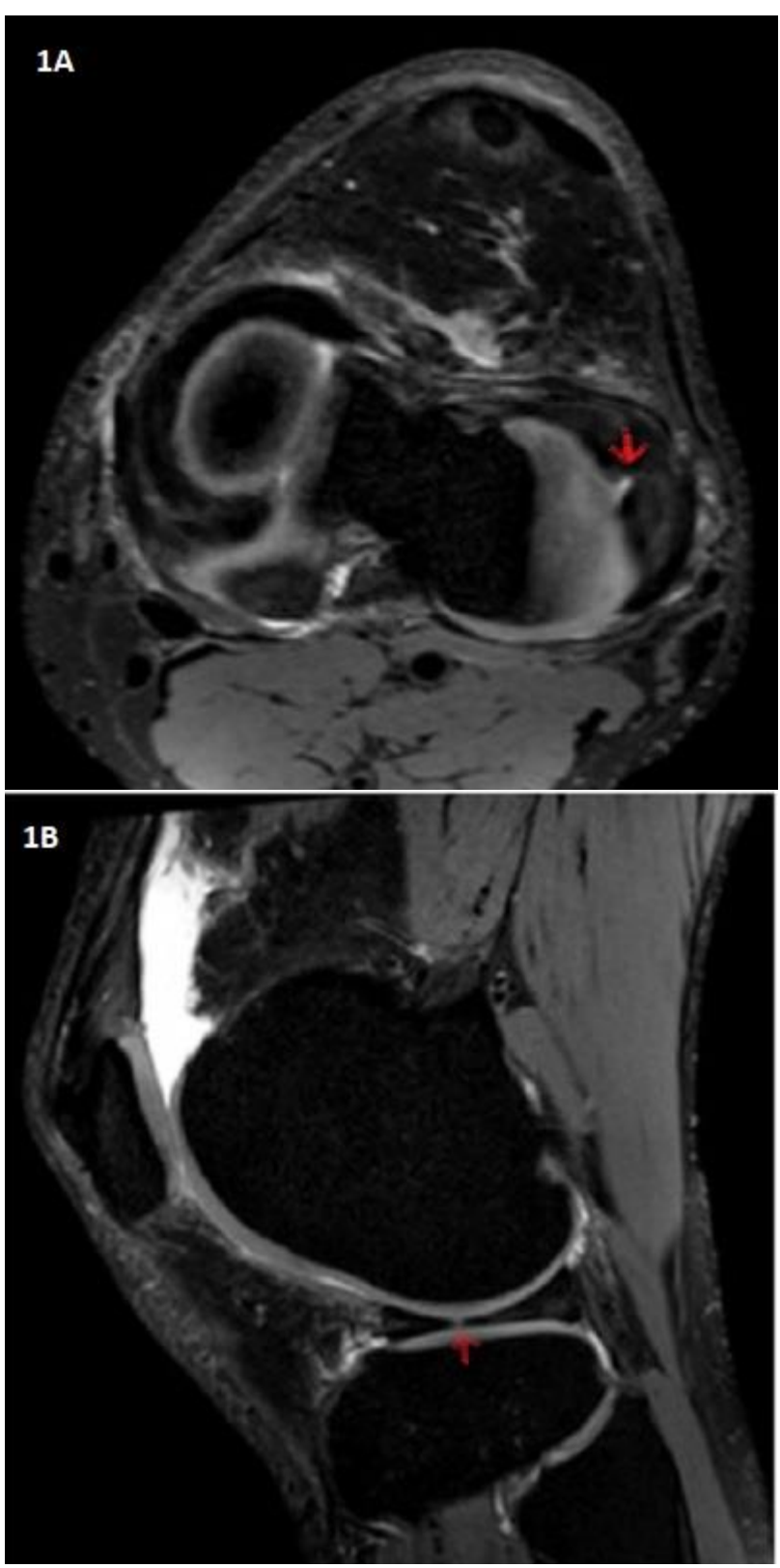

Figure 1. Focal radial tear is observed in the lateral meniscus, anterior horn-corpus junction, adjacent to the free edge (red arrow) on 3D PD VISTA Axial A and sagittal B sequences. The vertical radial tear on sagittal sections is perpendicularly oriented to the " $\mathrm{C}$ " shape of the meniscus in the axial plane.

Medial meniscal extrusion was observed in 11 cases $(36.7 \%)$ and lateral meniscal extrusion was observed in seven cases (23.3\%) (Table 2). 


\begin{tabular}{|c|c|c|c|c|c|c|c|c|}
\hline \multirow{2}{*}{\multicolumn{2}{|c|}{$\begin{array}{l}\text { Table } 2 \text {. The tab } \\
\text { focal-complete te } \\
\text { cases with menis } \\
\text { Age }\end{array}$}} & \multicolumn{3}{|c|}{ Min-Max } & \multirow{2}{*}{$\begin{array}{c}\text { Media } \\
\text { n }\end{array}$} & \multicolumn{3}{|c|}{ Mean \pm s.s./n-\% } \\
\hline & & 21 & - & $\begin{array}{l}7 \\
5\end{array}$ & & $\begin{array}{r}50, \\
3\end{array}$ & \pm & 14,2 \\
\hline \multirow[t]{2}{*}{ Gender } & Male & & & & & 19 & & $\begin{array}{c}63,3 \\
\%\end{array}$ \\
\hline & Female & & & & & 11 & & $\begin{array}{c}36,7 \\
\%\end{array}$ \\
\hline \multicolumn{2}{|c|}{ Medial Meniscus } & & & & & 17 & & $\begin{array}{c}56,7 \\
\%\end{array}$ \\
\hline & Focal & & & & & 8 & & $\begin{array}{c}26,7 \\
\%\end{array}$ \\
\hline & Complete & & & & & 9 & & $\begin{array}{c}30,0 \\
\%\end{array}$ \\
\hline & $\begin{array}{l}\text { Extrusion } \\
(-)\end{array}$ & & & & & 6 & & $\begin{array}{c}20,0 \\
\%\end{array}$ \\
\hline & $\begin{array}{l}\text { Extrusion } \\
(+)\end{array}$ & & & & & 11 & & $\begin{array}{c}36,7 \\
\%\end{array}$ \\
\hline \multicolumn{2}{|c|}{ Lateral Meniscus } & & & & & 13 & & $\begin{array}{c}43,3 \\
\%\end{array}$ \\
\hline & Focal & & & & & 9 & & $\begin{array}{c}30,0 \\
\%\end{array}$ \\
\hline & Complete & & & & & 4 & & $\begin{array}{c}13,3 \\
\%\end{array}$ \\
\hline & $\begin{array}{l}\text { Extrusion } \\
(-)\end{array}$ & & & & & 6 & & $\begin{array}{c}20,0 \\
\%\end{array}$ \\
\hline & $\begin{array}{l}\text { Extrusion } \\
(+)\end{array}$ & & & & & 7 & & $\begin{array}{c}23,3 \\
\%\end{array}$ \\
\hline
\end{tabular}

In this study, the most common ligament pathology that accompanied to radial tear was found to be anterior cruciate ligament (ACL) (17 cases, 56.9\%) and medial cruciate ligament (MCL) (14 cases, 46.6\%). Of the cases with ACL pathology, 13 (43.3\%) had mild injury, one (3.3\%) had partial tear and three (10\%) had full-thickness tear (Fig. 2A-B).

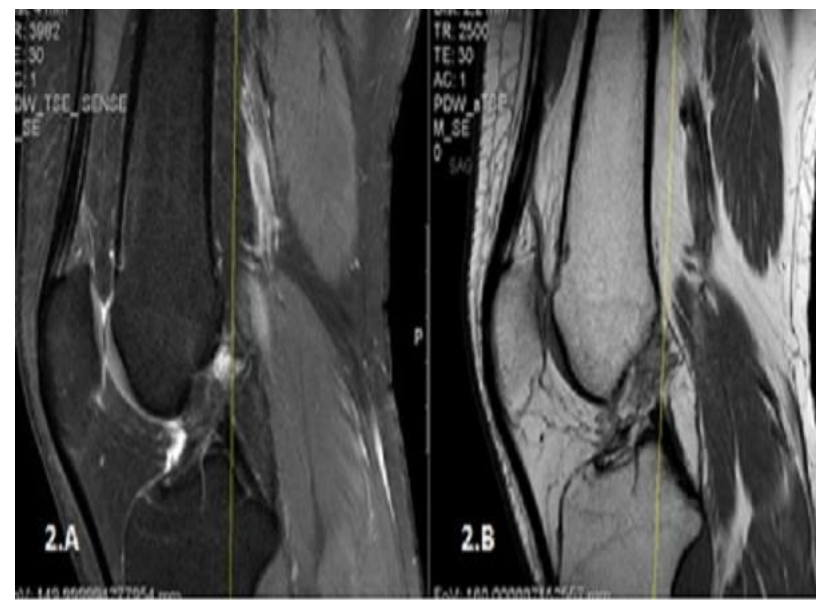

Figure 2. Full-thickness tear in the anterior cruciate ligament onsagittal T2W SPAIR A and sagittal PD B sequences.

Of the cases with MCL pathology, seven (23.3\%) had mild injury, seven $(23.3 \%)$ had partial tear. In 30 of the cases $(100.0 \%)$, posterior cruciate ligament (PCL) was normal, only one (3.3\%) patient had mild injury (Table 3 ).

\begin{tabular}{|c|c|c|c|}
\hline & & $\mathrm{n}$ & $\%$ \\
\hline \multirow[t]{4}{*}{ MCL } & Normal & 16 & $53,3 \%$ \\
\hline & Sprain & 7 & $23,3 \%$ \\
\hline & Partial tear & 7 & $23,3 \%$ \\
\hline & $\begin{array}{l}\text { Complete } \\
\text { tear }\end{array}$ & 0 & $0,0 \%$ \\
\hline \multirow[t]{4}{*}{ LCL } & Normal & 29 & $96,7 \%$ \\
\hline & Sprain & 1 & $3,3 \%$ \\
\hline & Partial tear & 0 & $0,0 \%$ \\
\hline & $\begin{array}{l}\text { Complete } \\
\text { tear }\end{array}$ & 0 & $0,0 \%$ \\
\hline \multirow[t]{4}{*}{ ACL } & Normal & 13 & $43,3 \%$ \\
\hline & Sprain & 13 & $43,3 \%$ \\
\hline & Partial tear & 1 & $3,3 \%$ \\
\hline & $\begin{array}{l}\text { Complete } \\
\text { tear }\end{array}$ & 3 & $10,0 \%$ \\
\hline \multirow[t]{4}{*}{ PCL } & Normal & 30 & $100,0 \%$ \\
\hline & Sprain & 0 & $0,0 \%$ \\
\hline & Partial tear & 0 & $0,0 \%$ \\
\hline & $\begin{array}{l}\text { Complete } \\
\text { tear }\end{array}$ & 0 & $0,0 \%$ \\
\hline
\end{tabular}

When the relationship between radial tear and cartilage pathologies was evaluated; cartilage degeneration was detected in the medial femoral condyle (MFC) of 14 cases (46.6\%), in the lateral femoral condyle (LFC) of 11 cases $(36.7 \%)$, in the lateral tibial plateau (LTP) of 16 cases $(53.3 \%)$ (Fig.3 A-B), in the medial patellar facet (MPF) of 26 cases $(86.6 \%)$, in the lateral patellar facet (LPF) of 16 cases $(53.4 \%)$ and in femoral trochlea (FT) of 15 cases $(50 \%)$.

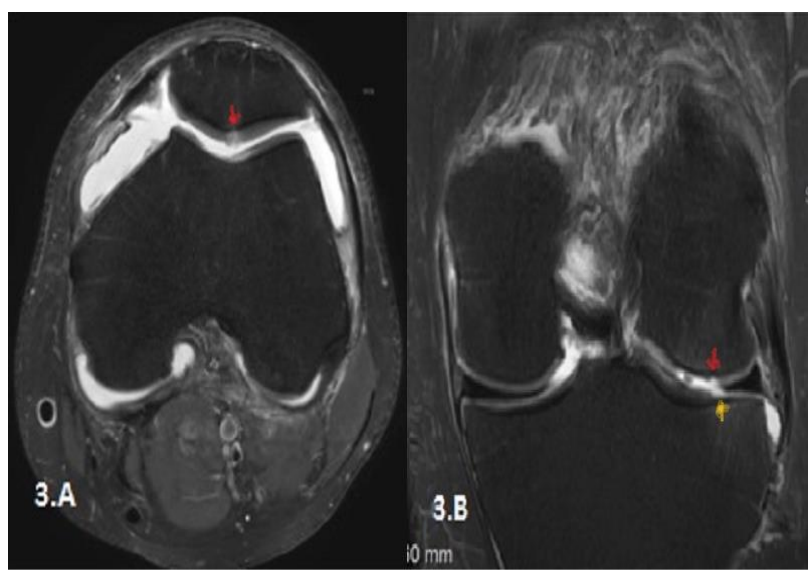

Figure 3. The chondral defect in the form of fissure which reaches to full-thickness at the lateral patellar facet-patellar ridge junction (red arrow) on axial PDW SPAIR A sequence, full-thickness chondral defects in the inferior part of lateral femoral condyle (red arrow) and lateral tibial plateau (yellow arrow) on coronal T2W SPAIR sequence B. 
The least affected cartilage was medial tibial plateau (MTP) and this pathology was detected in only five (16.7\%) patients (Table 4).

\begin{tabular}{|c|c|c|c|}
\hline \multicolumn{4}{|c|}{ Table 4. Ligament Pathologies Associated with } \\
\hline & & $\mathrm{n}$ & $\%$ \\
\hline \multirow[t]{4}{*}{ MFC } & None & 16 & $53,3 \%$ \\
\hline & Mild & 4 & $13,3 \%$ \\
\hline & Moderate & 4 & $13,3 \%$ \\
\hline & Advanced & 6 & $20,0 \%$ \\
\hline \multirow[t]{4}{*}{ LFC } & None & 19 & $63,3 \%$ \\
\hline & Mild & 3 & $10,0 \%$ \\
\hline & Moderate & 3 & $10,0 \%$ \\
\hline & Advanced & 5 & $16,7 \%$ \\
\hline \multirow[t]{4}{*}{ MTP } & None & 25 & $83,3 \%$ \\
\hline & Mild & 0 & $0,0 \%$ \\
\hline & Moderate & 2 & $6,7 \%$ \\
\hline & Advanced & 3 & $10,0 \%$ \\
\hline \multirow[t]{4}{*}{ LTP } & None & 14 & $46,7 \%$ \\
\hline & Mild & 6 & $20,0 \%$ \\
\hline & Moderate & 4 & $13,3 \%$ \\
\hline & Advanced & 6 & $20,0 \%$ \\
\hline \multirow[t]{4}{*}{ MPF } & None & 4 & $13,3 \%$ \\
\hline & Mild & 6 & $20,0 \%$ \\
\hline & Moderate & 10 & $33,3 \%$ \\
\hline & Advanced & 10 & $33,3 \%$ \\
\hline \multirow[t]{4}{*}{ LPF } & None & 14 & $46,7 \%$ \\
\hline & Mild & 6 & $20,0 \%$ \\
\hline & Moderate & 5 & $16,7 \%$ \\
\hline & Advanced & 5 & $16,7 \%$ \\
\hline \multirow[t]{4}{*}{ PR } & None & 15 & $50,0 \%$ \\
\hline & Mild & 0 & $0,0 \%$ \\
\hline & Moderate & 6 & $20,0 \%$ \\
\hline & Advanced & 9 & $30,0 \%$ \\
\hline \multirow[t]{4}{*}{ FT } & None & 15 & $50,0 \%$ \\
\hline & Mild & 3 & $10,0 \%$ \\
\hline & Moderate & 7 & $23,3 \%$ \\
\hline & Advanced & 5 & $16,7 \%$ \\
\hline
\end{tabular}

When the relationship between meniscus extrusion and cartilage degeneration was correlated, meniscal extrusion was observed $11(36.7 \%)$ of the cases with radial tear in the medial meniscus (n: 17, $56.7 \%$ ) and seven $(23.3 \%)$ of the cases with radial tear of the lateral meniscus (n: 13, 3). The degeneration of the MFC was observed in six $(20 \%)$ of 11 cases with medial meniscal extrusion and degeneration of LFC was observed in two $(6,6 \%)$ of seven cases with lateral meniscal extrusion. The grade of cartilage pathology that was observed in the MFC of 11 patients with medial meniscal extrusion was normal in $10 \%(3 / 11)$, moderate in $3.3 \%(1 / 11)$ and advanced in $23.3 \%$ (7/11). The grade of cartilage pathology that was observed in the LFC of seven patients with lateral meniscal extrusion was normal in $16.6 \%(5 / 7)$ and advanced in $6.6 \%(2 / 7)$.

\section{DISCUSSION}

Menisci have important mechanical functions in the knee. They absorb the shock, distribute the load on them, aid in joint lubrication. In case of insufficiency of cruciate ligaments or other primary stabilizers, they provide stability in the injured knee (2). Meniscal tears occur in the medial meniscus rather than the lateral meniscus. The tear is more common in the anterior horn of medial meniscus, since it is less mobile, rather than the posterior horn $(6,14)$. Meniscal tears are often categorized into five types as horizontal, longitudinal, radial, oblique (parrot-beak) and complex. Among these tears, radial tear is difficult to visualize on MRI (15). Tuckman et al. (1) identified the radial tears with $68 \%$ sensitivity using the criteria such as "truncation, abnormal morphology and / or loss or absence of continuity in meniscus" on one or more MR images. In addition to the studies of Tuckman et al. (1),Harper et al. (2) increased the sensitivity to $89 \%$ by observing increased signal intensity in the field of abnormal morphology on fat-suppressed coronal and sagittal T2-weighted or fat-suppressed sagittal proton density-weighted sequences. Radial tears appear in different shapes depending on their dimensions, orientations, localizations on MRI. They may be partial or full-thickness. The most easily diagnosed type of radial tears is fullthickness tear (2).

Lerer et al. (9) reported a strong relation between medial meniscal extrusion and meniscal root pathology, radial tear and degenerative joint disease. In the studies of Costa et al. (16), they demonstrated a significant relationship between medial meniscal extrusion and severe meniscal degeneration, advanced meniscal tears, complex tears, large radial tears, and meniscal root tears. Lee et al. (17) published that there is a high correlation between medial meniscal extrusion and meniscal root tears, degenerative joint disease, high grade cartilage defect (grade 3 and 4). In our study, only the patients with radial tears were evaluated. Medial meniscal extrusion is associated with radial tears $(36.7 \%, 11 / 17)$. The association between lateral meniscal extrusion and radial tear is not significant $(23.3 \%, 7 / 13)$.The body of the medial meniscus is extruded since a radial tear disrupts the circumferential fibers of meniscus. These fibers act like hoops on a wooden stave barrel and resist the outward stresses on the meniscus while bearing the weight on the knee. With disruption of these fibers by a radial tear, the body of the meniscus is 
displaced medially (18). There is a significant relationship between medial meniscal extrusion and moderate to advanced cartilage degeneration $(26.6 \%, 8 / 11)$. No significant relationship could be correlated between lateral meniscal extrusion and cartilage degeneration $(6.6 \%, 2 / 7)$.

Takahashi et al. (19) detected a significant coexistence in their research study which was published in 2015 and which correlated the association of root/ radial tears in the posterior horn of medial meniscus and the cartilage degeneration that was detected by the T1 cartilage mapping method. They reported that the morphological factors that were observed on the MRI of medial meniscus would be useful in the early stage screening of osteoarthritis.In our study, when the relationship between degenerative cartilage pathologies and meniscal radial tear was evaluated, cartilage degeneration was detected most commonly in MPF $(26 / 30,86.6 \%)$ and least commonly in MTP $(5 / 30,16.7 \%)$ in the medial part while it was detected most commonly in LPF $(16 / 30,53.4 \%)$ and least commonly in LFC (11/30, $36.7 \%$ ) in the lateral part.

According to our knowledge, there is no study that correlates the relationship between pure radial meniscal tears and ligament pathologies. Jeffrey et al. (10) correlated the relationship between lateral meniscal root tears (LMRT), meniscal extrusion and ACL. They stated that the patients in whom ACL tear was detected had LMRT rather than medial meniscal root tears (MMRT) and there was a relationship between LMRT, complex and radial tears and lateral meniscal extrusion. De Smet and Graf (20) reported that the patients with ACL tear had radial tears of lateral meniscus rather the radial tears of medial meniscus. In our study, the most common ligament pathology that accompanied to radial tear was full-thickness tear of ACL, without making lateral or medial discrimination. A possible mechanism is described in the literature for root tears which is a radial tear type, especially for lateral root tears: The reason is probably a relative compression of the bone insertion area of lateral meniscus during knee subluxation. It was suggested that characteristic anatomical features played an additionalrole. The anterior horn of lateral meniscus adheres to the tibia by blending partially with ACL. The anterior horn fibers of lateral meniscus are mixed with the anterior and lateral fibers of ACL. Due to the common insertion area of both ACL and the anterior horn of lateral meniscus, a tear may occur in the anterior horn of lateral meniscus during ACL injury (21). In MCL, most frequently mild injury and partial tear were observed. While PCL was normal in all cases, and mild injury of lateral collateral ligament (LCL) was observed only one case.

\section{CONCLUSION}

Radial tears frequently occur in the medial meniscus. While a vast percentage of medial meniscal radial tears are observed as complete radial tears, lateral meniscal radial tears are mostly focal tears. Extrusion to lateral is less commonly encountered finding in lateral meniscal radial tears while extrusion to medial $(\geq 3 \mathrm{~mm}$ ) frequently accompanies to medial meniscal radial tears. There is a significant relationship between medial meniscal extrusion and cartilage degeneration. No significant relationship could be correlated between lateral meniscal extrusion and cartilage degeneration. In radial meniscal tears, ACL pathology is observed rather than PCL pathology and MCL pathologies are observed rather than LCL pathology. It is observed that medial and lateral patellar facet cartilage is frequently affected in relation to radial tear and degenerative cartilage pathology.

\section{REFERENCES}

1. Glenn A. Tuckman, William J. Miller, John W. Remo, Hollis M. Frifts, Marc I. Rozansky. Radia ltears of the menisci: MR findings. AJR Am J Roentgenol. 1994 Aug;163(2):395-400.

2. Harper KW, Helms CA, Lambert HS 3rd, Higgins LD (2005) Radial meniscal tears: significance, incidence, and MR appearance. AJR Am J Roentgenol. 2005 Dec;185(6):142934.

3. Boyd KT, Myers PT. Meniscus preservation: rationale, repair techniques and results. Knee. 2003 Mar;10(1):1-11.

4. Eggli S, Wegmuller H, Kosina J, Huckell C, Jakob RP. Long-term results of arthroscopic meniscal repair: an analysis of isolated tears. Am J Sports Med. 1995 Nov-Dec;23(6):715-20.

5. Mink JH, Deutsch AL. Theknee. In: Mink JH, Deutsch AL, ads. MRI of the musculo skeletal system: a teaching file, 2nd ad. New York: Raven, 1990: 104-1

6. Ozkoc G, Circi E, Gonc U, Irgit K, Pourbagher A, Tandogan RN (2008) Radial tears in the root of the posterior horn of the medial meniscus. KneeSurg Sports TraumatolArthrosc. 2008 Sep;16(9):849-54

7. Rubin DA, Palella GA. Current concepts and controversies in meniscal imaging. In: Rubin
DA,
ed.
Update
on theknee. 
MagnResonImagingClin N Am. 2000 May;8(2):243-70.

8. Messner K, Gao J. The menisci of the knee joint: anatomical and functional characteristics, and a rational efor clinical treatment.J Anat. 1998 Aug;193 ( Pt 2):161-78.

9. D. B. Lerer, H. R. Umans, M. X. Hu, M. H. Jones. The role of meniscal root pathology and radial meniscal tear in medial meniscal extrusion. Skeletal Radiol. 2004 Oct;33(10):56974

10.Brody JM, Lin HM, Hulstyn MJ, Tung GA (2006) Lateral meniscus root tear and meniscus extrusion with anterior cruciate ligament tear. Radiology. 2006 Jun;239(3):805-10

11.Outerbridge RE. The etiology of chondromalacia patellae. J Bone JointSurgBr. 1961 Nov;43-B:752-7

12.Mink j, Levy T, Crues JI. Tears of th eanterior cruciate ligament and menisci of the knee: MR imaging evaluation. Radiology. 1988 Jun;167(3):769-74

13. Bergin D, Keogh C,O' Connell M, Rowe D, Shah B, Zoga A, et al. Atraumatic medial collateral ligament oedema in medial compartment knee osteoarthritis. SkeletalRadiol. 2002 Jan;31(1):14-8

14. Vedi V, Williams A, Tennant SJ, Spouse E, Hunt DM, Gedroyc WM. Meniscal movement: an in-vivo study using dynamic MRI.J Bone JointSurgBr. 1999 Jan;81(1):37-41.

15.Jee WH, McCauley TR, Kim JM, Jun DJ, Lee YJ, Choi BG, et al. Meniscal tear configurations: categorization with MR imaging. AJR Am J Roentgenol. 2003 Jan;180(1):93-7.

16. Costa CR, Morrison WB, Carrino JA. Medial meniscus extrusion on knee MRI: is extent associated with severity of degeneration or type of tear? AJR Am J Roentgenol. 2004 Jul;183(1):17-23.

17.Lee YG, Shim JC, Choi YS, Kim JG, Lee GJ, Kim HK (2008) Magnetic resonance imaging findings of surgically proven medial meniscus root tear: tear configuration and associated knee abnormalities. J ComputAssistTomogr. 2008 May-Jun;32(3):452-7.

18. De Smet AA. How I diagnose meniscal tears on knee MRI. AJR Am J Roentgenol. 2012 Sep;199(3):481-99

19.Takahashi K, Hashimoto S, Nakamura H, Mori A, Sato A, Majima T, et al. Medial meniscal posterior root horn radial tears correlate with cartilage degeneration detected by $\mathrm{T} 1 \rho$ relaxation mapping. Eur J Radiol. 2015 Jun;84(6):1098-104
20.De Smet AA, Graf BK. Meniscal tears missed on MR imaging: relationship to meniscal tear patterns and anterior cruciate ligament tears. AJR Am J Roentgenol. 1994 Apr;162(4):905-11.

21.Koo JH, Choi S-H, Lee SA, Wang JH (2015) Comparison of Medial and Lateral Meniscus Root Tears. PLoS ONE 10(10): e0141021. 